\title{
ANALISIS PENGENDALIAN INTERNAL TERHADAP PEMBAYARAN TOP UP FLAZZ PADA PT. TRANSJAKARTA
}

\author{
Andriyan ${ }^{1}$, Ridwan Saleh ${ }^{2}$ \\ ${ }^{1}$ STIE Muhammdiyah Jakarta, andriyan@stiemj.ac.id \\ ${ }^{2}$ STIE Muhammadiyah Jakarta, risalah_ak@yahoo.com
}

\begin{abstract}
ABSTRAK
PT. Transjakarta merupakan perusahaan transportasi yang menggunakan sistem tiket elektronik. Sistem tiket pada halte Transjakarta sejak 2013 menggunakan kartu elektronik (e-ticketing), sebagai pengganti uang tunai. Kartu tersebut salah satunya adalah kartu flazz yang dikeluarkan oleh Bank BCA. Namun pada setoran uang tunai dari penjualan top up flazz tersebut dari Transjakarta ke Bank Bca masih saja mengalami terkendala terdapat selisih di setiap harinya. Maka diperlukannya pengendalian internal dalam proses pembayaran serta rekonsiliasi antara data tagihan Bank Bca dengan pembayaran uang tunai top up di transjakarta tersebut. Selama ini kedua laporan yang seharusnya seimbang tersebut, pada kenyataannya tidak pernah terjadi. Oleh karena itulah perlu dilakukan rekonsiliasi dan dicari penyebab perbedaannya sehingga kemudian dapat dihasilkan laporan yang seimbang (balance). Penelitian ini bertujuan mengetahui implementasi pengendalian internal pada konsep komponen menurut COSO. Penulis menggunakan metode deskriptif dengan jenis analisis kualitatif, dengan mereview penerapan unsur-unsur pengendalian internal dengan mendeskripsikan fakta yang ada dilapangan, serta menganalisis penerapan unsur-unsur tersebut dengan mengacu pada COSO. Hasil menunjukkan bahwa secara umum pengendalian internal yang diterapkan pembayaran top up flazz telah memenuhi dan sesuai dengan konsep dan prinsip pengendalian internal menurut COSO. Namun pelaksanaan atas konsep komponen pengendalian internal perlu disempurnakan agar lebih efektif yaitu komponen lingkungan pengendalian,penilaian resiko dan pemantauan.
\end{abstract}

Kata Kunci: Pengendalian internal, top up.

\begin{abstract}
PT. Transjakarta is a transportation company that uses an electronic ticket system. The ticket system at the Transjakarta bus stop since 2013 uses an electronic card (e-ticketing), instead of cash. One of these cards is the Flazz card issued by Bank BCA. However, the cash deposit from the sale of the flazz top up from Transjakarta to Bank Bca still experiences constraints, there is a difference every day. Then the need for internal control in the payment process and reconciliation between Bank Bca billing data and top up cash payments in the Transjakarta. So far the two reports that should have been balanced, in fact never happened. That is why reconciliation is needed and the causes of the differences are sought so that a balanced report can be produced. This study aims to determine the implementation of internal control on the concept of components according to COSO. The author uses descriptive methods with the type of qualitative analysis, by reviewing the application of elements of internal control by describing the facts that exist in the field, and analyzing the application of these elements with reference to COSO. The results show that in general the internal controls applied for top up flazz payments have met and are in accordance with the concepts and principles of internal control according to COSO. However, the implementation of the concept of internal control components needs to be refined to be more effective, namely the environmental control, risk assessment and monitoring components.
\end{abstract}

Keywords: Internal control, top up. 


\section{PENDAHULUAN}

Untuk melindungi dan mempertahankan eksistensinya dalam persaingan dunia, setiap usaha menengah kecil harus dapat melakukan peningkatan dalam hal pengendalian internal yang merupakan bagian dari sebuah sistem yang harus dimiliki dalam melaksanakan kegiatan operasionalnya. Pengendalian Internal yaitu meliputi struktur organisasi, metode, dan ukuranukuran yang dikoordinasikan untuk menjaga kekayaan organisasi, mengecek ketelitian dan keandalan data akuntansi, mendorong efisiensi dan mendorong dipatuhinya kebijakan manajemen.

Pengendalian internal berperan penting dalam perusahaan karena semakin besar dan banyaknya operasi pada perusahaan, juga karena pengendalian internal merupakan suatu metode dan prosedur yang secara langsung atau tidak langsung yang dapat meminimalkan segala penyelewengan yang mungkin dapat merugikan perusahaan. Tujuan pengendalian internal ini dapat tercapai jika unsur-unsur pengendalian internal perusahaan itu terpenuhi dengan baik, agar pengendalian internal ini berjalan dengan efektif dan efisen. Diperlukan juga bagian tertentu bertugas untuk mengawasi dan mengevaluasi efektivitas dan efisiensi pengendalian internal.

Pengendalian internal perusahaan terdiri dari kebijakan dan prosedur yang ditetapkan untuk memberikan keyakinan yang memadai bahwa tujuan perusahaan akan dicapai karenanya harus diciptakan suatu sistem, prosedur, dan kebijaksanaan untuk menolong perusahaan mendapatkan jaminan dan pengamanan bahwa transaksi yang dijalankan sah dan dicatat secara wajar. Untuk menunjang keefektivan suatu pengendalian internal maka salah satu unsur yang penting adalah adanya suatu bagian dalam perusahaan yang bertugas menilai kelayakan dan keefektifan pengendalian internal yang ada dan menilai kualitas kegiatan yang telah dijalankan perusahaan

Peranan pengendalian internal dalam sebuah organisasi adalah sangat penting untuk pengendalian mencegah penggelapan (fraud). Organisasi banyak menggunakan pengendalian internal untuk mengetahui evaluasi kinerja dari organisasi tersebut yang terdiri dari efektivitas dan efisiensi operasi, keandalan pelaporan keuangan dan kepatuhan terhadap hukum dan peraturan yang berlaku.

PT.Transjakarta merupakan perusahaan transportasi yang menggunakan sistem tiket elektronik. Sistem tiket pada halte Transjakarta sejak 2013 menggunakan kartu elektronik (eticketing), sebagai pengganti uang tunai. Operator koridor tidak menerbitkan kartu tersebut, melainkan menggunakan kartu prabayar yang dikeluarkan oleh bank. Kartu tersebut salah satunya adalah kartu flazz yang dikeluarkan oleh Bank BCA. Namun pada setoran pembayaran uang tunai dari penjualan top up flazz tersebut dari transjakarta ke bank Bca masih saja mengalami terkendala terdapat selisih di setiap harinya. Maka diperlukannya pengendalian internal dalam proses pembayaran serta rekonsiliasi antara data tagihan Bank Bca dengan setoran pembayaran uang tunai top up di transjakarta tersebut. Selama ini kedua laporan yang seharusnya seimbang tersebut, pada kenyataannya tidak pernah terjadi. Oleh karena itulah perlu dilakukan rekonsiliasi dan dicari penyebab perbedaannya sehingga kemudian dapat dihasilkan laporan yang seimbang (balance). Didalam proses tersebut ada beberapa masalah yang dapat saya identifikasikan untuk kemudian akan saya coba menganalisanya dan memberikan alternatif solusi untuk mengatasi masalah-masalah tersebut serta memutuskan alternatif mana yang paling tepat dan cocok untuk digunakan.

Masalah-masalah tersebut diantaranya mencakup pengendalian internal, perbedaan sistem yang digunakan pada divisi yang berbeda dalam perusahaan, serta flow (alur) transaksi yang terkadang masih mengalami benturan antara aktivitas yang satu dengan aktivitas yang lainnya.

Alasan penulis mengambil perusahaan ini karena data-data yang tersedia berhubungan dengan judul yang di ambil penulis. Disamping itu, saya juga sangat tertarik untuk melakukan penelitian mengenai masalah pengendalian internal yang diterapkan suatu perusahaan terutama 


\section{JURNAL AKUNTANSI, Vol. 8, No. 1, April (2019)}

perusahaan yang berukuran relatif besar. Pengendalian internal merupakan salah satu indikator yang signifikan dalam penilaian kinerja suatu perusahaan. Dengan pengendalian internal yang telah diterapkan dengan baik maka biasanya efektivitas dan efisiensi didalam perusahaaan juga akan terlaksana secara optimal. Oleh sebab itulah setiap perusahaan membutuhkan pengendalian interrnal yang baik untuk setiap kegiatan yang berhubungan dengan siklus bisnis serta kegiatan operasi perusahaan itu sendiri. Semakin banyak kegiatan perusahaan yang dikerjakan, maka semakin banyak kemungkinan terjadinya kesalahan yang mengakibatkan penyimpangan pada perusahaan.

Berdasarkan uraian diatas maka penulis ingin menganalalisis mengenai analisis pengendalian internal terhadap pembayaran top up flazz pada pt. transjakarta.

\section{KAJIAN LITERATUR \\ Pengendalian Internal}

Menurut Hery dalam bukunya yang berjudul Pengendalian Akuntansi dan Manajemen (2014:11) menyatakan bahwa pengendalian internal adalah seperangkat kebijakan dan prosedur untuk melindungi aset atau kebijakan perusahaan dari segala bentuk tindakan penyalahgunaan, menjamin tersedianya informasi akuntansi perusahaan yang akurat, serta memastikan bahwa semua ketentuan (peraturan) hukum atau undang - undang serta kebijakan manajemen telah dipatuhi atau dijalankan sebagaimana mestinya oleh seluruh karyawan perusahaan.

\section{Unsur-unsur Pengendalian Internal}

Menurut COSO Pengendalian internal terdiri dari 5 (lima) komponen yang saling berhubungan. Komponen ini didapat dari cara manajemen menjalankan bisnisnya, dan terintegrasi dengan proses manajemen. Walaupun komponen-komponen tersebut dapat diterapkan kepada semua entitas, perusahaan yang kecil dan menengah dapat menerapkannya berbeda dengan perusahaan besar. Dalam hal ini pengendalian dapat tidak terlalu formal dan tidak terlalu terstruktur, namun pengendalian internal tetap dapat berjalan dengan efektif. Adapun 5 (lima) komponen Pengendalian internal tersebut adalah :

1. Lingkungan Pengendalian (Control Environment)

Lingkungan pengendalian perusahaan mencakup sikap para manajemen dan karyawan terhadap pentingnya pengendalian yang ada di organisasi tersebut. Ada beberapa komponen dalam pengendalian lingkungan antara lain :

a) Filosofi manajemen dan gaya operasi

b) Integritas dan nilai-nilai etika

c) Komitmen terhadap kompetensi

d) Cara manajemen untuk menentukan wewenang dan tanggung jawab dan mengorganisasikan dan mengembangkan orang-orangnya, dan

e) Perhatian dan arahan yang diberikan dewan direksi.

2. Risk Assesment (Penilaian Resiko)

Seluruh entitas menghadapi berbagai macam resiko dari luar dan dalam yang harus ditaksir. Prasyarat dari Risk Assessment adalah penegakan tujuan, yang terhubung antara tingkatan yang berbeda, dan konsisten secara internal. Risk Assessment adalah proses mengidentifikasi dan menganalisis resiko-resiko yang relevan dalam pencapaian tujuan, membentuk sebuah basis untuk menentukan bagaimana resiko dapat diatur. Karena kondisi ekonomi, industri, regulasi, dan operasi selalu berubah, maka diperlukan mekanisme untuk mengidentifikasi dan menghadapi resiko-resiko spesial terkait dengan perubahan tersebut. Semua organisasi memiliki resiko, dalam kondisi apapun yang namanya resiko pasti ada dalam suatu aktivitas, baik aktivitas yang berkaitan dengan bisnis (profit dan non profit) maupun non bisnis. Suatu resiko yang telah di identifikasi 


\section{JURNAL AKUNTANSI, Vol. 8, No. 1, April (2019}

dapat di analisis dan evaluasi sehingga dapat di perkirakan intensitas dan tindakan yang dapat meminimalkannya. Sebuah pengendalian internal yang baik memungkinkan penaksiran resiko yang dihadapi oleh organisasi baik ynag berasal dari dalam meupun dari luar organisasi. Langkah-langkah dalam penaksiran resiko adalah sebagai berikut :

a) Mengidentifikasi faktor-faktor yang mempengaruhi risiko

b) Menaksir resiko yang berpengaruh cukup signifikan

c) Menentukan tindakan yang dilakukan untuk me-manage risiko

d) Dewan direksi

e) Struktur organisasi

f) Tugas tanggung jawab dan otoritas

g) Kebijakan SDM dan Prektek

h) Pengaruh eksternal.

3. Control Activities (Kegiatan Pengendalian)

Control Activities adalah kebijakan dan prosedur membantu meyakinkan manajemen bahwa arahannya telah dijalankan. Control Activities membantu meyakinkan bahwa tindakan yang diperlukan telah diambil dalam menghadapi resiko sehingga tujuan entitas dapat tercapai. Control Activities terjadi pada seluruh organisasi, pada seluruh level, dan seluruh fungsi. Aktivitas pengendalian meliputi:
a) Pemisahan fungsi/tugas/wewenang yang cukup
b) Otorisasi traksaksi dan aktivitas lainnya yang sesuai
c) Pendokumentasiaan dan pencatatan yang cukup
d) Pengendalian secara fisik terhadap aset dan catatan
e) Evaluasi secara independen atas kinerja
f) Pengendalian terhadap pemrosesan informasi
g) Pembatasan akses terhadap sumberdaya dan catatan
4. Informasi dan Komunikasi

Informasi yang bersangkutan harus diidentifikasi, tergambar dan terkomunikasi dalam sebuah form dan timeframe yang memungkinkan orang-orang menjalankan tanggung jawabnya. Sistem informasi menghasilkan laporan, yang berisi informasi operasional, finansial, dan terpenuhinya keperluan sistem, yang membuatnya mungkin untuk menjalankan dan mengendalikan bisnis. Informasi dan Komunikasi tidak hanya menghadapi data-data yang dihasilkan internal, tetapi juga kejadian eksternal, kegiatan dan kondisi yang diperlukan untuk memberikan informasi dalam rangka pembuatan keputusan bisnis dan laporan eksternal. Komunikasi yang efektif juga harus terjadi dalam hal yang lebih luas, mengalir ke bawah, ke samping dan ke atas organisasi. Seluruh personel harus menerima dengan jelas pesan dari manajemen teratas bahwa pengendalian tanggung jawab diambil dengan serius. Para personel harus mengerti peran mereka dalam sistem pengendalian internal, sebagaimana mereka mengerti bahwa kegiatan individu mereka berhubungan dengan pekerjaan orang lain. Mereka harus memiliki niat untuk mengkomunikasikan informasi yang signifikan kepada atasannya. Selain itu juga dibutuhkan komunikasi efektif dengan pihak eksternal, seperti customer, supplier, regulator, dan Pemegang Saham.

5. Pemantauan (Monitoring)

Sistem pengendalian internal perlu diawasi, sebuah proses untuk menentukan kualitas performa sistem dari waktu ke waktu. Proses ini terselesaikan melalui kegiatan pengawasan yang berkesinambungan, evaluasi yang terpisah atau kombinasi dari keduanya. Kegiatan ini termasuk manajemen dan supervisi yang reguler, dan kegiatan lainnya yang dilakukan personel dalam menjalankan tugasnya. Luas dan frekuensi evaluasi terpisah, akan tergantung pada terutama penaksiran resiko dan efektifnya prosedur monitoring yang sedang berlangsung. Ketergantungan sistem pengendalian harus dilaporkan kepada atasan, dengan masalah yang serius juga dilaporkan kepada manajemen teratas dan dewan direksi. 


\section{JURNAL AKUNTANSI, Vol. 8, No. 1, April (2019)}

Menurut COSO, semua orang dalam organisasi yaitu Manajemen, Dewan direksi, Komite Audit, dan Personel lainnya bertanggung jawab terhadap pengendalian internal, karena semua orang dalam organisasi memiliki peran dalam pengendalian internal, sehingga pengendalian internal tidak dapat berjalan dengan baik apabila ada salah satu anggota yang tidak menjalankan perannya dalam pengendalian internal. Pihak-pihak luar seringkali memberikan kontribusi terhadap pencapaian tujuan perusahaan, seperti Auditor eksternal, Badan Regulasi dan legislatif, customer, analis keuangan, dan media massa. Namun demikian pihak ketiga tersebut tidak bertanggung jawab terhadap pengendalian internal karena mereka bukan bagian dari organisasi maupun bukan bagian dari sistem pengendalian internal.

Pemantauan terhadap sistem pengendalian intern akan menemukan kekurangan serta meningkatkan efektivitas pengendalian. Pengendalian intern dapat di monitor dengan baik dengan cara penilaian khusus atau sejalan dengan usaha manajemen. Usaha pemantauan yang terakhir dapat dilakukan dengan cara mengamati perilaku karyawan atau tanda-tanda peringatan yang diberikan oleh sistem akuntansi. Penilaian secara khusus biasanya dilakukan secara berkala saat terjadi perubahan pokok dalam strategi manajemen senior, struktur korporasi atau kegiatan usaha. Pada perusahaan besar, auditor internal adalah pihak yang bertanggung jawab atas pemantauan sistem pengendalian intern. Auditor independen juga sering melakukan penilaian atas pengendalian intern sebagai bagian dari auditor atas laporan keuangan. Pemantauan seharusnya menilai kualitas kinerja sepanjang waktu dan menyakinkan bahwa temuan-temuan audit dan review lainnya diselesaikan dengan tepat. Hal ini meliputi:

a) Mengevaluasi temuan-temuan, review, rekomendasi audit secara tepat.

b) Menentukan tindakan yang tepat untuk menanggapi temuan dan rekomendasi dari audit dan reviu.

c) Menyelesaikan dalam waktu yang telah ditentukan tindakan yang digunakan untuk menindaklanjuti rekomendasi yang menjadi perhatian manajemen.

\section{Tanggung Jawab atas Pengendalian Internal}

Manajemen bertanggung jawab untuk menyiapkan laporan bagi pihak investor, kreditur serta pihak yang berkepentingan. Tanggung jawab mulai untuk memilih dan mengadopsi kebijakan akuntansi yang tepat, menyelenggarakan pelaksanaan pengendalian internal, serta menyajikan laporan keuangan yang wajar semua ada di pihak manajemen. Manajemen bertanggung jawab untuk merancang dan menerapkan sistem pengendalian internal serta melaporkan secara transparan perihal efektivitas pelaksanaannya.

Menurut Mulyadi dalam bukunya yang berjudul Auditing (2014:181) menyatakan bahwa pihak-pihak yang bertanggung jawab terhadap pengendalian internal yaitu sebagai berikut:

1) Manajemen

Manajemen memiliki tanggung jawab untuk mengembangkan dan menyelenggarakan secara efektif pengendalian internal organisasinya.

2) Dewan komisaris dan komite audit

Dewan Komisaris bertanggung jawab untuk menentukan apakah manajemen telah memenuhi tanggung jawab mereka dalam mengembangkan dan menyelenggarakan pengendalian internal.

3) Auditor intern

Bertanggung jawab untuk memeriksa dan mengevaluasi memadai atau tidaknya pengendalian internal entitas dan membuat rekomendasi peningkatannya.

4) Personel lain entitas 


\section{JURNAL AKUNTANSI, Vol. 8, No. 1, April (2019}

Peran dan tanggung jawab semua personel lain yang menyediakan informasi atau menggunakan informasi yang dihasilkan oleh pengendalian internal harus ditetapkan dan dikomunikasikan dengan baik.

5) Auditor independen

Sebagai bagian dari prosedur auditnya terhadap laporan keuangan, auditor dapat menemukan kelemahan pengendalian internal kliennya, sehingga ia dapat mengkomunikasikan temuan auditnya tersebut kepada manajemen, komite audit atau dewan komisaris.

6) Pihak luar lain

Pihak luar lain yang bertanggung jawab atas pengendalian internal entitas adalah badan pengatur, seperti Bank Indonesia dan Bapepam.

Berdasarkan Undang-undang Sarbanes-Oxley, manajemen dari semua perusahaan publik harus menerbitkan laporan pengendalian internal yang mencakup hal-hal :

a. Suatu pernyataan bahwa manajemen bertanggung jawab untuk menetapkan dan menyelenggarakan struktur pengendalian internal yang memadai serta prosedur pelaporan keuangan.

b. Suatu penilaian atas efektivitas struktur pengendalian internal dan prosedur pelaporan keuangan per akhir tahun buku perusahaan.

Penilaian manajemen mengenai pengendalian internal atas pelaporan keuangan terdiri dari 2 (dua) komponen utama, yaitu evaluasi rancangan pengendalian internal dan pengujian efektivitas pelaksanaan pengendalian.

Manajemen harus mengevaluasi apakah pengendalian telah dirancang dan diterapkan untuk mencegah atau menemukan salah saji material atas pelaporan keuangan. Fokus manajemen pada pengendalian atas semua asersi yang terkait dengan semua akun serta pengungkapannya, termasuk mengevaluasi bagaimana transaksi di otorisasi, dicatat, diproses, dan dilaporkan. Manajemen harus menguji efektivitas pelaksanaannya untuk memastikan bahwa penerapannya telah sesaui dengan yang dirancang serta dilaksanakan oleh personel yang memiliki kewenangan dan kualifikasi untuk melaksanakan pengendalian internal secara efektif. Dan terakhir manajemen harus mengungkapkan setiap penemuan kelemahan pengendalian internal yang material dan mendokumentasikan hasil pengujian tersebut.

\section{Studi Empiris}

Beberapa penelitian terdahulu akan diuraikan secara ringkas karena penelitian ini mengacu pada beberapa penelitian sebelumnya. Meskipun ruang lingkup hampir sama tetapi karena obyek dan periode waktu yang digunakan berbeda maka terdapat banyak hal yang tidak sama sehingga dapat dijadikan sebagai referensi untuk saling melengkapi.

Berikut ringkasan beberapa penelitian terdahulu:

a) Penelitian Putu Mega Selvya Avyana (2012), Unika Widya Mandala berjudul, "Penerapan Pengendalian Internal dalam Sistem Informasi Akuntansi Berbasis Komputer PT. Transavia Otomasi Pratama" Menyimpulkan bahwa penggunaan sistem informasi akuntansi, tidak lepas dari resiko-resiko yang ada baik kesalahan yang disengaja seperti penipuan, tindak kebohongan untuk mendapatkan keuntungan dan tidak sengaja seperti seperti salah memasukan nama atau kode pelanggan. Untuk meminimalkan risiko-risiko yang mungkin terjadi terkait dengan penggunaan sistem informasi akuntansi untuk mencapai tujuan dari perusahaan tersebut.

b) Penelitian Sri Wahyuni, STIESIA Surabaya (2013), berjudul Pelaksanaan Sistem Pengendalian Intern terhadap Prosedur Penerimaan dan Pengeluaran Barang pada UD. Dwi Jaya Sentosa Surabaya menyimpulkan bahwa adanya perangkapan fungsi yang dilakukan oleh bagian penerimaan barang dengan bagian penyimpanan barang (gudang) disebabkan tidak adanya pemisahan fungsi secara jelas dalam bagian ini. 


\section{JURNAL AKUNTANSI, Vol. 8, No. 1, April (2019)}

c) Penelitian Yudi Rahman, STIE Pancasetia Banjarmasin (2014) berjudul Analisis Sistem dan Prosedur Pengendalian Internal Penerimaan Kas pada UD. Sumber Makiah Loktabat, Banjarbaru menyimpulkan bahwa penerapan sistem dan prosedur pengendalian intern masih lemah hal ini dapat dilihat dari perangkapan fungsi didalam pelaksanaan tugas khususnya pada bagian administrasi yaitu bagian pembukuan merangkap tugasnya sebagai kasir dan juga melakukan tugas sebagai pembukuan (pencatatan).

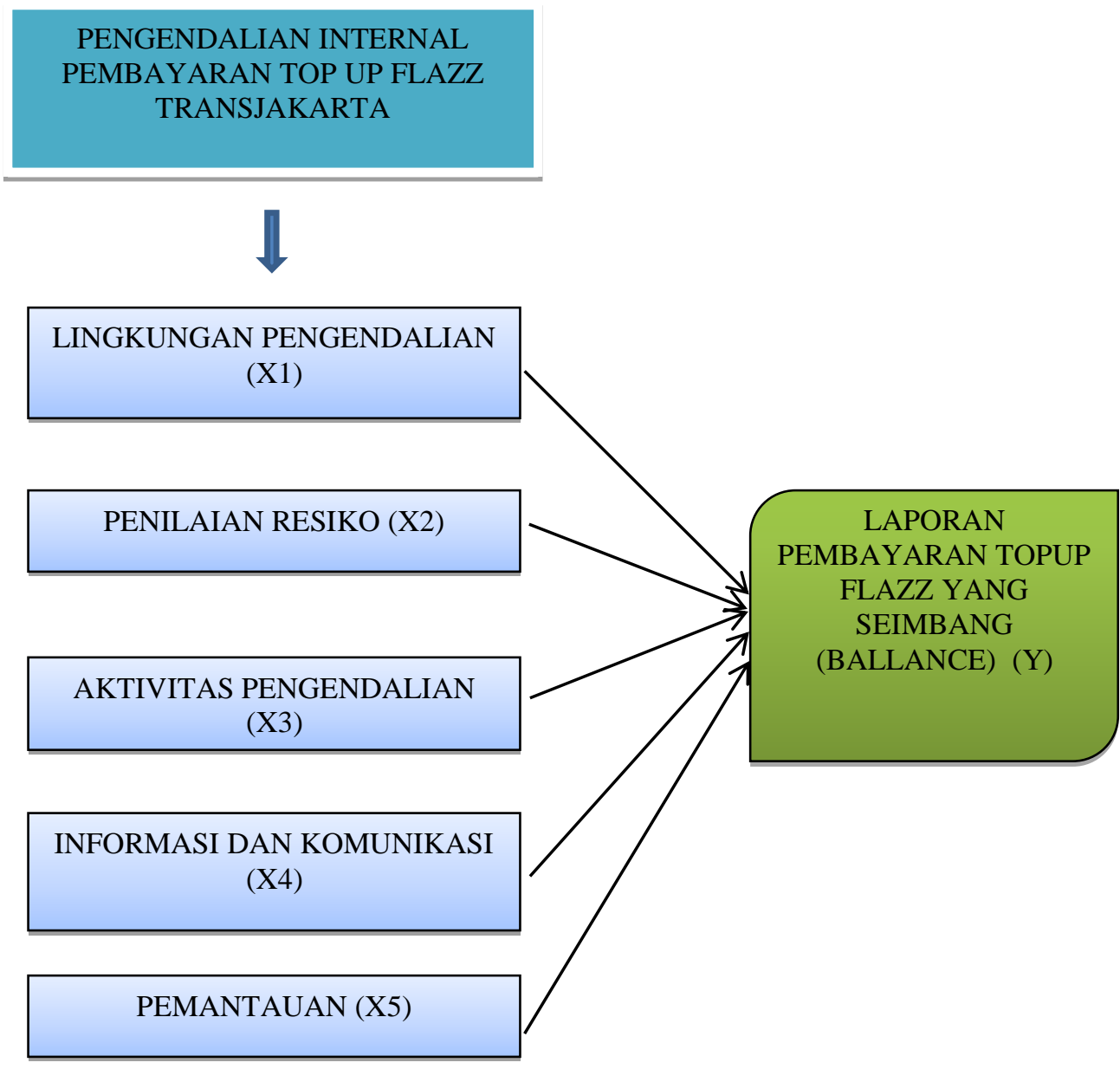

Gambar 2 Kerangka Pemikir

METODE PENELITIAN 


\section{JURNAL AKUNTANSI, Vol. 8, No. 1, April (2019}

\begin{tabular}{|c|c|c|c|}
\hline No. & Uraian & $\mathrm{Ya}$ & Tidak \\
\hline & Lingkungan Pengendalian & & \\
\hline 1. & Apakah perusahaan memiliki struktur organisasi? & $\mathrm{V}$ & \\
\hline 2. & $\begin{array}{l}\text { Apakah terdapat suatu kebijakan tertentu perusahaan di dalam proses } \\
\text { pembayaran top up flazz? }\end{array}$ & $\mathrm{V}$ & \\
\hline 3. & $\begin{array}{l}\text { Apakah manajemen membuat laporan penjualan top up flazz untuk } \\
\text { setiap kasir? }\end{array}$ & $\mathrm{V}$ & \\
\hline 4. & $\begin{array}{l}\text { Apakah setiap tindakan yang dilakukan oleh bagian kasir, korlap } \\
\text { penjualan, kolektor uang, tim settlemen, sudah patuh dan disiplin } \\
\text { terhadap kebijakan yang berlaku? }\end{array}$ & & $\mathrm{V}$ \\
\hline 5. & $\begin{array}{l}\text { Apakah dalam proses pembayaran top up flazz karyawan konsisten } \\
\text { menjalankan prinsip kehati-hatian? }\end{array}$ & & $\mathrm{V}$ \\
\hline 6. & $\begin{array}{l}\text { Apakah terdapat rotasi karyawan di dalam divisi sistem tiket } \\
\text { transjakarta? }\end{array}$ & $\mathrm{V}$ & \\
\hline 7. & $\begin{array}{l}\text { Apakah setiap karyawan pada divisi sistem tiket mendapatkan } \\
\text { pelatihan terlebih dahulu? }\end{array}$ & $\mathrm{V}$ & \\
\hline 8. & $\begin{array}{l}\text { Apakah karyawan pada divisi sistem tiket memiliki latar belakang } \\
\text { pendidikan yang berbeda-beda? }\end{array}$ & $\mathrm{V}$ & \\
\hline 9 & $\begin{array}{l}\text { Apakah jajaran direksi berpartisipasi dalam proses pembayaran top } \\
\text { up flazz? }\end{array}$ & & $\mathrm{V}$ \\
\hline 10. & $\begin{array}{l}\text { Apakah fungsi dan tugas dalam struktur organisasi memiliki } \\
\text { ketentuan tertulis? }\end{array}$ & $\mathrm{V}$ & \\
\hline 11. & $\begin{array}{l}\text { Apakah ada tindakan manajemen yang dilaksanakan secara intensif } \\
\text { untuk mengurangi karyawan yang berbuat tidak jujur? }\end{array}$ & & $\mathrm{V}$ \\
\hline \multirow[t]{2}{*}{12.} & $\begin{array}{l}\text { Apakah terdapat kebijakan dalam proses kepegawaian upaya untuk } \\
\text { mendapatkan SDM yang jujur dan kompeten dalam tugasnya? }\end{array}$ & $\mathrm{V}$ & \\
\hline & Penaksiran Resiko & & \\
\hline 13. & $\begin{array}{l}\text { Apakah terdapat sistem pengelolaan resiko pada Transjakarta } \\
\text { terhadap pembayaran top up flazz? }\end{array}$ & & $\mathrm{V}$ \\
\hline \multirow[t]{2}{*}{14.} & $\begin{array}{l}\text { Apakah seluruh pihak yang terkait dalam pembayaran top up flazz } \\
\text { memiliki pemahaman mengenai manajemen resiko? }\end{array}$ & & $\mathrm{V}$ \\
\hline & $\begin{array}{l}\text { Apakah manajemen melakukan penaksiran resiko atas kemungkinan } \\
\text { terjadinya selisih pembayaran top up flazz yang meliputi kejadian } \\
\text { internal yang timbul karena: }\end{array}$ & & \\
\hline 15. & $\begin{array}{l}\text { Penempatan karyawan baru dalam aktivitas pembayaran top up } \\
\text { flazz? }\end{array}$ & $\mathrm{V}$ & \\
\hline 16. & $\begin{array}{l}\text { Sosialisasi penggunaan teknologi informasi baru dalam aktivitas } \\
\text { pembayaran top up flazz? }\end{array}$ & $\mathrm{V}$ & \\
\hline \multirow[t]{2}{*}{17.} & $\begin{array}{l}\text { Apakah auditor internal dilibatkan dalam proses pembayaran top up } \\
\text { flazz? }\end{array}$ & & $\mathrm{V}$ \\
\hline & Aktivitas Pengendalian & & \\
\hline 18 & Apakah fungsi akuntansi terpisah dengan pembayaran top up flazz? & $\mathrm{V}$ & \\
\hline 19. & Apakah dibuat laporan penjualan top up flazz untuk setiap kasir? & $\mathrm{V}$ & \\
\hline 20. & $\begin{array}{l}\text { Apakah pencatatan laporan penjualan kasir didasarkan pada bukti } \\
\text { transaksi top up flazz dan dilampirkan dengan dokumen yang } \\
\text { lengkap? }\end{array}$ & $\mathrm{V}$ & \\
\hline 21. & $\begin{array}{l}\text { Apakah kasir menerima uang dari penumpang dan menghitungnya } \\
\text { sebelum diserahkan kepada korlap penjualan? }\end{array}$ & $\mathrm{V}$ & \\
\hline 22. & Apakah bagian korlap penjualan cukup memeriksa dan menhitung & $\mathrm{V}$ & \\
\hline
\end{tabular}




\section{JURNAL AKUNTANSI, Vol. 8, No. 1, April (2019)}

\begin{tabular}{|c|c|c|c|}
\hline & kembali hasil penjualan pada setiap kasir ? & & \\
\hline 23. & $\begin{array}{l}\text { Apakah kolektor kartu dan uang cukup memeriksa dan } \\
\text { menghitungmya kembali hasil penjualan top up flazz yang diterima } \\
\text { dari korlap penjualan? }\end{array}$ & V & \\
\hline 24. & $\begin{array}{l}\text { Apakah tim settlement cukup memeriksa dan menghitungnya } \\
\text { kembali hasil penjualan top up flazz yang diterima dari kolektor } \\
\text { kartu dan uang? }\end{array}$ & V & \\
\hline 25. & $\begin{array}{l}\text { Apakah petugas rekonsiliasi/PIC flazz cukup memeriksa dan } \\
\text { mengitungnya kembali hasil penjualan yang diterima dari tim } \\
\text { settlement? }\end{array}$ & $\mathrm{V}$ & \\
\hline 26. & $\begin{array}{l}\text { Apakah dilakukan rekonsiliasi data tagihan dari Bank Bca dengan } \\
\text { bagian sistem tiket Transjakarta untuk memastikan pembayarannya? }\end{array}$ & V & \\
\hline 27. & $\begin{array}{l}\text { Apakah bukti pembayaran top up flazz terdiri dari beberapa rekapan } \\
\text { dan didistribusikan kepada bagian yang berbeda guna kepentingan } \\
\text { pengawasan internal? }\end{array}$ & V & \\
\hline 28. & $\begin{array}{l}\text { Apakah pembayaran hasil setoran top up flazz diperiksa terlebih } \\
\text { dahulu sebelum diberikan kepada pihak Bank BCA? }\end{array}$ & V & \\
\hline 29. & Apakah dibuat berita acara pembayaran top up flazz ke Bank Bca? & $\mathrm{V}$ & \\
\hline 30. & $\begin{array}{l}\text { Apakah seluruh dokumen penting telah disimpan pada tempat yang } \\
\text { aman dan akses terbatas? }\end{array}$ & $\mathrm{V}$ & \\
\hline 31. & Apakah terdapat segel pengaman untuk uang penjualan top up flazz? & & $\mathrm{V}$ \\
\hline 32. & $\begin{array}{l}\text { Apakah dibuat serah terima uang penjualan top up flazz antara } \\
\text { masing-masing petugas yang terkait? }\end{array}$ & & $\mathrm{V}$ \\
\hline 33. & $\begin{array}{l}\text { Apakah setiap petugas yang terkait uang penjualan top up flazz } \\
\text { membuat catatan tersendiri? }\end{array}$ & & $\mathrm{V}$ \\
\hline \multirow[t]{2}{*}{34.} & $\begin{array}{l}\text { Apakah ada pengawalan khusus perjalanan uang penjualan top up } \\
\text { flazz mulai dari halte-halte sampai ke kantor transjakarta? }\end{array}$ & & $\mathrm{V}$ \\
\hline & Informasi dan Komunikasi & & \\
\hline 35. & Apakah transjakarta memiliki sistem informasi yang memadai? & $\mathrm{V}$ & \\
\hline 36. & $\begin{array}{l}\text { Apakah terdapat sistem dokumentasi yang memadai terkait } \\
\text { pembayaran top up flazz? }\end{array}$ & & $\mathrm{V}$ \\
\hline 37. & $\begin{array}{l}\text { Apakah manajemen Transjakarta melakukan tukar menukar } \\
\text { informasi kepada pihak bank Bca mengenai kendala yang terjadi } \\
\text { pada aktivitas pembayaran top up flazz? }\end{array}$ & & $\mathrm{V}$ \\
\hline \multirow[t]{2}{*}{38.} & $\begin{array}{l}\text { Apakah terdapat sistem informasi yang mencakup metode dan } \\
\text { catatan untuk menggambarkan dengan dasar yang tepat transaksi- } \\
\text { transaksi yang cukup rinci untuk membenarkan pengklasifikasian } \\
\text { dari transaksi pembayaran top up flazz? }\end{array}$ & $\mathrm{V}$ & \\
\hline & Pemantauan & & \\
\hline 39. & $\begin{array}{l}\text { Apakah ada unit kerja khusus yang bertanggung jawab atas proses } \\
\text { pembayaran top up flazz? }\end{array}$ & & $\mathrm{V}$ \\
\hline 40. & $\begin{array}{l}\text { Apakah ada hal yang dilakukan Transjakarta jika terjadi } \\
\text { penyimpangan khususnya dalam proses pembayaran top up flazz? }\end{array}$ & & $\mathrm{V}$ \\
\hline 41. & $\begin{array}{l}\text { Apakah audit internal ikut serta dalam memantau pada saat } \\
\text { pembayaran top up flazz? }\end{array}$ & & $\mathrm{V}$ \\
\hline 42. & $\begin{array}{l}\text { Apakah ada pola tertentu dan membina karyawan yang terkait } \\
\text { pembayaran top up flazz agar tidak terjadi kecurangan dalam } \\
\text { aktivitas tersebut? }\end{array}$ & V & \\
\hline
\end{tabular}

Sumber : diolah penulis 2017 


\section{JURNAL AKUNTANSI, Vol. 8, No. 1, April (2019}

\section{Pelaporan Hasil Temuan dan Rekomendasi}

Lingkungan Pengendalian

1. Setiap tindakan yang dilakukan oleh bagian kasir, korlap penjualan, kolektor uang, tim settlemen, belum sepenuhnya patuh dan disiplin terhadap kebijakan yang berlaku.

2. Di dalam proses pembayaran top up flazz, karyawan masih banyak yang belum konsisten menjalankan prinsip kehati-hatian.

3. Belum adanya tindakan manajemen yang dilaksanakan secara intensif untuk mengurangi karyawan yang berbuat tidak jujur.

4. Jajaran direksi tidak ikut berpartisipasi dalam proses pembayaran top up flazz.

Penaksiran Resiko

1. Belum terdapat sistem pengelolaan resiko pada Transjakarta terhadap pembayaran top up flazz.

2. Seluruh pihak yang terkait dalam pembayaran top up flazz belum memiliki pemahaman mengenai manajemen resiko.

3. Auditor internal tidak dilibatkan dalam proses pembayaran top up flazz.

Aktivitas Pengendalian

1. Tidak terdapat segel pengaman untuk uang penjualan top up flazz.

2. Tidak dibuat serah terima uang penjualan top up flazz antara masing-masing petugas yang terkait.

3. Setiap petugas yang terkait uang penjualan top up flazz tidak membuat catatan tersendiri.

4. Tidak ada pengawalan khusus perjalanan uang penjualan top up flazz mulai dari halte-halte sampai ke kantor transjakarta.

Informasi dan Komunikasi

1. Tidak terdapat sistem dokumentasi yang memadai terkait pembayaran top up flazz.

2. Manajemen Transjakarta masih belum melakukan pertemuan tukar menukar informasi kepada pihak bank Bca mengenai kendala yang terjadi pada aktivitas pembayaran top up flazz.

Pemantauan

1. Tidak ada unit kerja khusus yang bertanggung jawab atas proses pembayaran top up flazz.

2. Belum diberlakukan sanksi yang dilakukan Transjakarta jika terjadi penyimpangan khususnya dalam proses pembayaran top up flazz.

3. Audit internal tidak ikut serta dalam memantau pada saat pembayaran top up flazz.

Rekomendasi yang disarankan untuk pengendalian internal pembayaran top up flazz.

1. Setiap tindakan yang dilakukan oleh bagian kasir, korlap penjualan, kolektor uang, tim settlement,sudah harus sepenuhnya patuh dan disiplin terhadap kebijakan yang berlaku, guna untuk menghindari terjadinya selisih pada pembayaran top up flazz.

2. Di dalam proses pembayaran top up flazz, harus diterapkan setiap karyawan untuk konsisten menjalankan prinsip kehati-hatian agar tidak terjadinya selisih pada uang pembayaran top up flazz.

3. Jajaran kepala seksi harus ikut berpartisipasi dalam proses pembayaran top up flazz untuk mengetahui jika terjadinya selisih dan untuk menindak bawahannya guna mengurangi terjadinya kecurangan.

4. Manajemen harus melakukan tindakan yang dilaksanakan secara intensif untuk mengurangi karyawan yang berbuat tidak jujur, misalnya rotasi pekerjaan, rotasi tempat tugas, bahkan diterapkan Surat Pernyataan jika memungkinkan. 


\section{JURNAL AKUNTANSI, Vol. 8, No. 1, April (2019)}

5. Manejemen sudah seharusnya menerapkan sistem pengelolaan resiko pada Transjakarta terhadap pembayaran top up flazz, untuk menghindari terjadinya resiko selisih yang lebih besar.

6. Harus segera di informasikan kepada seluruh pihak yang terkait dalam pembayaran top up flazz mengetahui memahami mengenai manajemen resiko.

7. Untuk pemeriksaan rutin Auditor internal mulai harus dilibatkan dalam proses pembayaran top up flazz, untuk mencegah karyawan melakukan kecurangan pada pembayaran setoran top up flazz.

8. Manajemen harus mengadakan segel pengaman untuk uang penjualan top up flazz agar aman sampai serah terima ke Bank Bca.

9. Harus dibuat serah terima uang penjualan top up flazz antara masing-masing petugas yang terkait, untuk saling menjadi saksi pada saat serah terima uang pembayaran top up flazz.

10. Setiap petugas yang terkait uang penjualan top up flazz harus membuat catatan tersendiri untuk mencocokkan kembali jika terjadi selisih di kemudian hari.

11. Manajemen harus memikirkan mengenai pengawalan khusus perjalanan uang penjualan top up flazz mulai dari halte-halte sampai ke kantor transjakarta guna untuk mencegah hal-hal yang terjadi yang tidak diinginkan.

12. Perlunya sistem dokumentasi yang memadai terkait pembayaran top up flazz, untuk menjadi bukti jika terjadi selisih dikemudian hari.

13. Manajemen Transjakarta sebaiknya melakukan pertemuan tukar menukar informasi kepada pihak bank Bca mengenai kendala yang terjadi pada aktivitas pembayaran top up flazz, guna untuk saling sharing mencegah terjadinya selisih pada pembayaran top up flazz.

14. Dengan adanya unit kerja khusus yang bertanggung jawab atas proses pembayaran top up flazz, perusahaan menjadi mudah untuk mengelola, memantau, serta menindak setiap karyawan terkait pembayaran top up flazz.

15. Harus segera diberlakukan sanksi yang dilakukan Transjakarta jika terjadi penyimpangan khususnya dalam proses pembayaran top up flazz, guna untuk mendapatkan efek jera bagi karyawan yang melakukan kecurangan serta mencegahnya.

16. Untuk pemantauan maksimal diperlukan audit internal pembayaran top up flazz.

\section{Analisa dan Pembahasan Penelitian}

Berdasarkan hasil internal control quisioner maka diperoleh kesimpulan dalam pengendalian internal pembayaran top up flazz

PT. Transjakarta telah menerapkan fungsi dan unsur- unsur pengendalian secara efeketif. Langkah awal yang dilakukan adalah dengan merubah pribadi-pribadi karyawan untuk menerapkan patuh dan disiplin terhadap kebijakan-kebijakan yang berlaku serta konsisten dalam pelaksanaannya terutama dilingkungan yang terkait pembayaran top up flazz. Perubahan tersebut menjadikan kelebihan bagi PT. Transjakarta karena semua transaksi yang dilakukan oleh divisi sistem tiket mendapatkan pengawasan dari manajemen, serta proses pembayaran top up flazz dapat dilakukan secara cepat, tepat dan akurat yaitu seimbang dengan data tagihan dari Bank Bca.

Pembagian tugas dalam perusahaan sesuai struktur organisasi sudah dilakukan dengan masing-masing tanggung jawab serta perincian tugasnya. Pembagian tugas telah dilakukan secara baik dengan membagi kegiatan operasional di PT. Transjakarta menjadi beberapa divisi yang mempunyai tugas dan wewenang berbeda begitu pula karyawan yang bertugas dilapangan dibagi menjadi beberapa bagian yang memiliki tugas dan wewenang yang berbeda pula. Dalam melaksanakan tugas dan wewenang baik di kantor PT. Transjakarta maupun karyawan bertugas dilapangan harus mendapatkan otorisasi dari pihak yang memiliki wewenang dimulai dari manajer distribusi tiket, kepala seksi tiket, dewan direksi hingga dewan komisaris. 


\section{JURNAL AKUNTANSI, Vol. 8, No. 1, April (2019}

Dalam hal perekrutan karyawan baru PT. Transjakarta telah menerapkan standarisasi pendidikan dan kompetensi sehingga karyawan baru dapat dengan cepat menyesuaikan diri dengan lingkungan perusahaan dan dapat menjalankan tugas dan wewenang yang diberikan dengan baik. Proses pembayaran top up flazz dilakukan secara baik bahkan dimulai setiap harinya. Dimulai dari petugas kasir yang menyerahkannya kepada korlap penjualan kemudian diteruskan ke masing-masing kolektor tiket untuk dibawa ke kantor transjakarta dan diserahkan kepada tim settlement untuk melakukan pengecekan, dan dilanjutkan kepada petugas rekonsiliasi untuk rekapitulasi, penghitungan kembali, pencocokan serta pembayaran hasil penjualan top up flazz dengan pihak bank.

Demikian halnya dengan bagian audit internal telah melaksanakan, memantau dan menerapkan prosedur sebagaimana mestinya kepada seluruh karyawan terutama divisi sistem tiket guna mencegah terjadinya kecurangan yang dilakukan oleh karyawan.

\section{PENUTUP}

Berdasarkan uraian yang dijelaskan di atas maka penulis mengambil kesimpulan bahwa sistem tiket transjakarta merupakan salah satu divisi yang sangat penting di PT. Transjakarta. Bukan hanya karena banyaknya karyawan yang dikendalikan dan transaksi top up yang cukup besar setiap harinya tapi juga begitu banyak celah yang dapat menyebabkan kemungkinan terjadinya fraud yang melanggar kebijakan dan dapat merugikan perusahaan. Oleh karena itu, pengendalian internal di dalam divisi tiket transjakarta yang efektif dan efisien sangatlah diperlukan untuk mengurangi kemungkinan adanya kerugian perusahaan karena fraud.

Hasil menunjukkan bahwa secara umum pengendalian internal yang diterapkan pembayaran top up flazz telah memenuhi dan sesuai dengan konsep dan prinsip pengendalian internal menurut COSO. Namun pelaksanaan atas konsep komponen pengendalian internal perlu disempurnakan agar lebih efektif yaitu komponen lingkungan pengendalian, penilaian resiko dan pemantauan. Masih terdapat berbagai kekurangan terutama pada proses pembayaran pengisian ulang (top up) yang dapat mengganggu kegiatan operasional perusahaan, sehingga perlu dilakukan perbaikan yang memadai untuk mengatasinya. Namun pelaksanaan atas konsep komponen pengendalian internal perlu disempurnakan agar lebih efektif yaitu komponen lingkungan pengendalian, penilaian resiko dan pemantauan. Bahkan sebenarnya apabila hal ini terus dibiarkan, kemungkinan dapat mengakibatkan efek yang buruk bagi perusahaan.

Kondisi ini dapat diibaratkan seperti gejala penyakit, pada awalnya gejaka ini memang belum memiliki efek yang terlalu serius dan berbahaya. Gejala-gejala ini walaupun belum terasa parah dan membahayakan namun merupakan suatu indikasi adanya penyakit yang di masa depan memiliki kemungkinan untuk menjadi parah dan berbahaya, bahkan dapat menyebabkan kematian. Oleh karena itulah, setiap penyakit bahkan gejalanya sekalipun harus segera diobati agar tidak bertambah parah dan mengakibatkan efek yang lebih fatal dan lebih berbahaya lagi. Perlakuan yang sama juga berlaku pada sebuah perusahaan.

Selain itu masalah pendokumentasian dokumen-dokumen penunjang yang digunakan dalam suatu transaksi juga masih dapat dikatakan kurang. Hal ini dapat terlihat dari proses serah terima transaksi setoran top up flazz. Selama ini belum tersedia prosedur baku yang dibuat untuk setiap transaksi serah terima setoran top up flazz. Akibatnya laporan pembayaran top up flazz sering terjadi kekurangan jumlah fisik uang ketika pada saat direkonsiliasi.

Melihat fakta-fakta yang ada, maka saya pribadi berpendapat bahwa masalah-masalah yang sudah teridentifikasi diatas perlu diatasi dengan segera dan dilakukan penanganan dengan serius agar tidak berlanjut dan menimbulkan akibat yang lebih besar bagi perusahaan. Adapun alternatif yang menurut saya cocok untuk diterapkan diantaranya adalah:

a. Yang pertama kali harus dilakukan adalah menyusun "Standar Operasional Prosedur" (SOP). Penyusunan SOP ini sebaiknya dilakukan dengan menyesuaikan kondisi yang ada sekarang. Prosedur yang digunakan terkesan masih sangat mengacu dan mengadopsi pada kondisi prosedur lama. Sedangkan sebenarnya prosedur yang lama tersebut sudah cocok lagi dengan kondisi yang ada. Khususnya mengenai transaksi setoran top up flazz. Contoh 


\section{JURNAL AKUNTANSI, Vol. 8, No. 1, April (2019)}

nyata yang dapat dilakukan diantaranya adalah menyusun flowchart dari transaksi top up flazz. Kemudian mempublikasikannya kepada karyawan dan mengaplikasikannya secara maksimal. Hal ini dimaksudkan untuk memperbaiki dan meningkatkan pengendalian internal di dalam perusahaan.

b. Sedangkan untuk mengatasi masalah dalam proses pendokumentasian dapat dilakukan dengan cara me-review yang telah ada, kemudian mengidentifikasikan dokumen lain yang diperlukan untuk mengcover dan menutupi kekurangan ada. Dan yang terakhir adalah mengaplikasikannya dalam kegiatan operasional sehari-hari.

\section{REFERENSI}

Agoes, Sukrisno. 2012. Auditing. Edisi 4 Buku 1, Jakarta: Salemba Empat

Heni, 2011, Analisa Pengendalian Internal Sistem penagihan Jasa, http://library.gunadarma.ac.id/repository/view/9633/analisa-pengendalianinternal-sistempenagihan-jasa-penyedia-layanantelekomunikasi-aksesinternettelkomspeedy-pada-pttelkom.html/, Diakses pada tanggal 3 April 2017

Hery, 2013, Akuntansi Keuangan Menengah”, CAPS (Center Academic Publishing Service), Yogyakarta

Hery, 2014, Pengendalian Akuntansi dan Manajemen, Jakarta: Kencana Ikatan Akuntan Indonesia. 2011. Standar Profesional Akuntan Publik. Jakarta: Salemba Empat

Mufid Siregar, 2016, Sistem Manajemen Transjakarta, https://mufidjetsiregars.wordpress.com/2016/04/05/sistem-manajemen- transjakarta/.

Diakses pada tanggal 07 Maret 2017

Muhamad Fadlan, 2007, Sistem Ticketing TransJakarta Berbasis Smart Card Menggunakan

JakCard. Skripsi, Universitas Gunadarma

Mulyadi. 2014. Sistem Akuntansi. Yogyakarta: Salemba Empat

Pratiwi, 2012, Aalisis Penggunaan Uang Elektronik, http://library.gunadarma.ac.id/repository/view/3774508/analisis- penggunaan-uang

elektronik-di-kalangan-masyarakat-studi-kasus- pengguna-kartu-flazz-bca.html/. Diakses pada tanggal 15 Maret 2017

PT. Transjakarta, 2016, Struktur Organisasi, http://transjakarta.co.id/tentangtransjakarta/struktur-organisasi/. Diakses pada tanggal 05 April 2017

Putu Mega, 2012, Penerapan Pengendalian Internal dalam sistem Informasi Akuntansi, http://journal.wima.ac.id/index.php/JIMA. Diakses pada tanggal 19 Maret 2017

Sri Wahyuni, 2013, Sistem Pengendalian Internal terhadap Prosedur Penerimaan Barang, https://ejournal.stiesia.ac.id/jira/article/view/96. Diakses pada tanggal 01 Maret 2017

Standar Profesional Akuntan Publik (SPAP). 2011. PSA No.04 SA Seksi 230. InstitutAkuntan Publik Indonesia. Jakarta

Tuanakotta, Theodorus M. 2013. Audit berbasis ISA (International Standards on Auditing).Jakarta: Salemba Empat

Tunggal, Amin Widjaja. 2014. Konsep dan Studi Kasus Internal Auditing. Jakarta: Salemba Empat. 